\title{
EM NOME DA HONRA: A TUTELA DA DIGNIDADE PESSOAL E O DIREITO PENAL
}

IN THE NAME OF HONOR: THE PROTECTION OF PERSONAL DIGNITY AND CRIMINAL LAW

Ricardo Freitas ${ }^{1}$

Faculdade Damas/PE

\begin{abstract}
Resumo
O texto aborda o problema da proteção da honra pelo direito com base no exame das variadas alternativas empregadas na defesa da dignidade pessoal na história. Argumenta-se que a resposta penal às ofensas que causam um dano à respeitabilidade da pessoa ajusta-se às exigências de uma moral aristocrática tradicional e, por conseguinte, não se compatibiliza com as demandas da sociedade brasileira contemporânea nem com o direito penal liberal.
\end{abstract}

Palavras-chaves

Honra. Dignidade Pessoal. Direito Penal. Duelo. Legítima Defesa da Honra. Intervenção Mínima.

\begin{abstract}
The text approaches the problem of the protection of the honor by the law through the examination of different alternatives employed in the defense of personal dignity throughout history. It is argued that Criminal response to the offenses that damages the personal respectability are adjusted to the demands of a traditional aristocratic moral and, therefore, does not suits the demands of the current Brazilian society, nor of the liberal Criminal Law.
\end{abstract}

Keywords

Honor. Personal Dignity. Criminal Law. Duel. Self-defense of the Honor. Minimal Intervention.

\section{INTRODUÇÃO: PROTEÇÃO DA DIGNIDADE DA PESSOA HUMANA E DIREITO PENAL MÍNIMO.}

O ser humano merece ser protegido contra o desprezo e a humilhação de seus semelhantes. Todo homem tem o direito de ser respeitado em sua humanidade, o que equivale a dizer que a honra de cada um deve ser objeto de tutela do direito contra aqueles que pretendem atingi-la.

A doutrina penal nacional conceitua a honra enquanto bem jurídico como "aquele complexo ou conjunto de predicados ou condições da pessoa que lhe confere consideração social e estima própria” (NORONHA, 1996, p.116). Os penalistas compartilham o entendimento de que, em termos objetivos, a honra corresponde à avaliação formulada por determinado segmento social a respeito das qualidades e defeitos de determinada

\footnotetext{
${ }^{1}$ Professor do Programa de Pós-graduação em Direito da Faculdade Damas da Instrução Cristã. Procurador do Ministério Público Militar da União.
} 
pessoa. Em termos subjetivos, a honra diz respeito à autoestima, ou seja, ao "sentimento pessoal da própria dignidade"; enquanto, objetivamente, ela "apresenta-se como a consideração e o respeito" que cercam a pessoa no meio social ou, em outras palavras, a honra é a sua respeitabilidade. Enquanto no primeiro sentido a honra é denominada de honra subjetiva, no segundo ela é chamada de honra objetiva. Malgrado esta distinção, Bruno (1976, p.269) alerta, com toda razão, para o fato de que a honra apresenta uma estrutura unitária, na medida em que a respeitabilidade e o sentimento pessoal de dignidade de um ser humano estão intimamente vinculados, considerando-se, por exemplo, que a vítima de difamação também não deixa de ser atingida reflexamente em sua autoestima. Portanto, em última análise, admitindo-se que a honra subjetiva e a honra objetiva compõem um todo indivisível, pode-se afirmar que aquilo que se encontra em jogo quando se trata da honra é a dignidade pessoal do ser humano.

Referir-se à honra pessoal é o mesmo que aludir à respeitabilidade. Todo ser humano merece consideração e respeito de seus semelhantes. A honra é, assim, por definição, "algo que existe aos olhos dos outros" (GRAEBER, 2016, p.215). Nas palavras precisas de Appiah (2012, p.13): "Nós, seres humanos, precisamos que os outros respondam apropriadamente ao que somos e ao que fazemos". Este aspecto essencial da honra será bastante enfatizado neste texto, muito embora, nos termos expostos anteriormente, honra objetiva e subjetiva estejam entrelaçadas.

Há um amplo consenso entre os juristas de que a honra é um objeto jurídico, vale dizer, um objeto de proteção do direito, porém, certamente é necessário discutir se ela também deve ser um específico objeto jurídico-penal, ou seja, um bem jurídico merecedor de tutela por parte do direito penal. Porque o sentido da honra tem se transformado de maneira constante e profunda no curso da história faz-se indispensável repensar seu conceito à luz das transformações sociais e indagar se este bem jurídico reveste-se ou não de dignidade penal na atualidade. Na realidade, ao final e ao cabo, o instrumento a ser utilizado para a proteção da honra pessoal há de depender, em última análise, da visão prevalecente nas comunidades humanas contemporâneas acerca do conteúdo do valor "dignidade pessoal".

Pretende-se explorar neste texto certas dimensões do valor "honra" com base no exame de determinados contextos históricos particularizados nos quais a honra adquiriu conteúdos que exigiram a criminalização de condutas suscetíveis de lhe causarem lesão. Pretende-se também fazê-lo em consideração à permissão historicamente frequente concedida pelo direito penal aos ofendidos em sua honra para, em nome do ideal da autodefesa, reagir legitimamente contra as agressões a ela perpetradas por terceiros.

2 “O conceito de 'valor' não pode rigorosamente definir-se. Pertence ao número daqueles conceitos supremos, como os de 'ser', 'existência', etc., que não admitem definição. Tudo o que pode fazer-se a respeito deles é simplesmente tentar uma clarificação ou demonstração de seu conteúdo” (HESSEN, 1980, p.37). 
Objetiva-se, por derradeiro, demonstrar, na hipótese dos delitos contra a honra, a natureza necessariamente provisória e contingente das opções político-criminais do legislador penal e da sociedade em determinados momentos históricos. Para tanto, o texto socorrese da concepção político-penal minimalista, a saber, aquela que assegura um máximo de liberdades ao indivíduo contra o arbítrio estatal. Mais especificamente em relação à problemática em análise, preside o desenvolvimento deste ensaio a noção de subsidiariedade, segundo a qual a intervenção do direito penal para a tutela de bens jurídicos legitima-se unicamente se inexistentes meios extrapenais ou extrajurídicos capazes de lhes assegurar uma proteção eficiente com menor custo para os indivíduos e para a sociedade.

Partindo do pressuposto de que a honra é um bem fundamental da vida social, o texto explora as diferentes alternativas de tutela da dignidade penal no curso da história com o objetivo de demonstrar que, mesmo em sociedades afastadas no tempo, a dignidade pessoal do ser humano não foi necessariamente protegida mediante sanções direcionadas ao corpo ou a liberdade do agente. Em seguida, avalia, com base na instituição do duelo, como muitas vezes a legislação relacionada ao problema da honra encontra-se em descompasso com a visão dos pensadores do direito penal e de determinados segmentos da sociedade. Algumas vezes o direito adianta-se no tempo e atropela os costumes tradicionais, como ocorreu no caso do duelo; em outras, talvez mais frequentemente, ele atrasa-se e entra em conflito com as ideias e práticas de um mundo transformado, como ocorre atualmente com a legislação penal brasileira no que diz respeito aos crimes contra a honra. Os capítulos subsequentes trazem algumas situações em que isto ocorre, como no caso da admissão por parte da jurisprudência e da doutrina da legítima defesa da honra, inclusive por parte dos militares. Por fim, o texto evidencia que o discurso da honra se faz presente também na fundamentação da inexistência de obrigação por parte do titular de um bem jurídico empreender a fuga quando na iminência de sofrer uma agressão injusta, contrariando, assim, os dois fundamentos doutrinários da legítima defesa: o princípio da autotutela (princípio individual) e o princípio da prevalência do direito sobre o injusto (princípio coletivo).

\section{A HONRA COMO BEM FUNDAMENTAL DA VIDA SOCIAL: AS DIFERENTES ALTERNATIVAS DE TUTELA DA DIGNIDADE PENAL NO CURSO DA HISTÓRIA.}

A honra é um bem jurídico, vale dizer, é um interesse avaliado de maneira positiva pela coletividade por ser considerado, corretamente, como essencial para a reprodução da vida social e para o adequado desenvolvimento da personalidade humana. Portanto, a honra é um valor positivo ou, simplesmente, um valor. Mas a honra não é um objeto valioso em si mesmo, pois, para sê-lo, depende da avaliação positiva que os indivíduos fazem a seu respeito. Esta avaliação, diga-se de passagem, não é de modo algum inteiramente subjetiva, 
na medida em que todo e qualquer indivíduo "pertence a uma época e, como ser social, se insere sempre na rede de relações de determinada sociedade", encontrando-se, da mesma forma, "imerso numa dada cultura, da qual se nutre espiritualmente, e a sua apreciação das coisas ou dos seus juízos de valor se conformam com regras, critérios e valores que não inventa ou descobre pessoalmente e que têm, portanto, significação social" (SÁNCHEZ VÁSQUEZ, 2002, p.143).

Pelo fato de serem socialmente objetivados, os valores sociais modificam-se com o tempo mediante mudanças que alteram as circunstâncias peculiares que os originaram em um dado momento histórico numa comunidade humana específica. Produto da cultura, os valores são afetados pela evolução cultural, adquirindo novos conteúdos. Por vezes, inclusive, valores são substituídos por outros e o valor "honra" não representa uma exceção à regra.

Na antiguidade clássica, Aristóteles (2001, p.88), baseado em sua doutrina da mediania, sustentou o ponto de vista de que o termo médio da honra seria a magnificência, ao passo que a jactância seria o excesso e a pusilanimidade o defeito, ou melhor, a insuficiência de honra. De acordo com o filósofo, aquele indivíduo que aspira honra maior do que aquela que lhe é devida não passa de um ambicioso ou amante da honra, enquanto que o homem que não a aspira como deveria fazê-lo é simplesmente uma pessoa carente de ambição.

No limiar do período clássico de seu passado, os atenienses puniam severamente os autores de ofensas à honra. A legislação atribuída a Sólon proibia expressamente injúrias no interior dos templos, durante as assembleias ou no transcorrer dos jogos públicos, cominando pena de multa no valor de cinco dracmas ao infrator, quantia repartida entre o ofendido (três dracmas) e o Erário (dois dracmas) (THONISSEN, 1875, p.279). Aparentemente, o legislador ateniense pretendeu que o direito intervisse na esfera da honra não somente para tutela-la, mas também para assegurar a ordem pública.

No tratamento legal conferido pelo direito ateniense aos comportamentos ofensivos à honra pessoal chama a atenção o sentimento isonômico implícito na legislação, o que não se observa em absoluto na concepção aristotélica. Independentemente do status social do sujeito ativo e do sujeito passivo do delito, o primeiro deveria ser punido exatamente da mesma maneira sem qualquer privilégio decorrente de sua condição social ou econômica. Em todos os casos lhe era cominada uma quantidade fixa de pena pecuniária. Em contraste, no passado do direito penal proliferaram exemplos de aplicação desigual de sanções com fundamento tanto na origem social do infrator e da vítima como na posição econômica ou nas atividades que desempenhavam no âmbito da comunidade política.

$\mathrm{Na}$ antiga Roma, somente com a evolução do direito penal romano as ofensas contra a honra passaram a ser castigadas penalmente. Registre-se que, originariamente, o crime de injúria se referia ao comportamento que causava lesões corporais ou dano à condição 
jurídica da vítima. A ampliação do conceito de injúria ocorreu a partir do alargamento das hipóteses que permitiam a ação do mesmo nome. A Lei das Doze Tábuas, por exemplo, excluía das ações de injúria as ofensas contra a honra, de maneira que o reconhecimento da existência de um delito contra a honra dependia fundamentalmente do arbítrio judicial. Os magistrados só concediam a ação de injúria nos delitos contra a honra que se revestissem de significativa gravidade em consideração às circunstâncias especiais que os revestiam, prática que redundava em significativo nível de desigualdade diante da lei (MOMMSEN, 1999, p.486-487).

Na Irlanda, no início da Idade Média, tutelava-se a honra de toda pessoa livre, mas não da mesma maneira. Todo dano causado à dignidade pessoal importava em uma sanção pecuniária, o chamado "preço da honra". Assim, por exemplo, o "preço da honra" de um monarca (chefe) tribal consistia em sete unidades monetárias cujo pagamento podia ser substituído pelo repasse de sete meninas escravas, embora esta última hipótese raramente ocorresse na prática. O "preço da honra" de um bispo ou de um mestre da poesia era exatamente o mesmo devido ao monarca. Porém, no dia a dia, a sanção aplicada pela ofensa à dignidade destas pessoas notáveis resumia-se ao pagamento de 21 vacas leiteiras ou a mesma quantidade em onças de ouro. Por sua vez, a ofensa à honra de um camponês próspero era reparada mediante o pagamento de duas onças e meia de ouro, ao passo que a honra de um pequeno senhor de terras era satisfeita com este mesmo valor acrescido de meia vaca para cada um dos dependentes livres que possuísse. Em se tratando de uma mulher livre, a sanção pela violação de sua honra era fixada em metade do valor do "preço da honra" de seu parente mais próximo do sexo masculino - seu pai ou seu marido, na hipótese do primeiro ter falecido. Se uma mulher "desonrada" fosse ofendida em sua dignidade, o infrator teria que pagar um "preço da honra" equivalente ao que pagaria se tivesse ofendido a um homem, mas desde que ela fosse proprietária de terras. Caso contrário, o "preço a honra" deveria ser pago pelo ofensor a um parente da ofendida. Excluía-se apenas da proteção do direito a mulher de "costumes fáceis" por entender-se que ela não tinha honra a ser protegida (GRAEBER, 2016, p.222-225). Percebe-se, dessa maneira, que o direito irlandês tratava desigualmente as pessoas no que diz respeito à tutela da honra em razão do status socioeconômico e do gênero do ofendido. Em todos os casos, porém, a ofensa à honra importava exclusivamente numa sanção pecuniária mesmo que o ofendido fosse um monarca tribal ou uma autoridade religiosa.

Exemplos como os anteriormente citados demonstram suficientemente que nem sempre a privação da liberdade do autor de uma ofensa contra a honra foi a resposta dada pelo direito penal, pois sanções de natureza pecuniária também se fizeram presentes no curso da história. 
Mas a tutela da honra por intermédio da pena nem sempre se constituiu na única alternativa penal destinada à sua conservação, merecendo registro, igualmente, o costume do duelo e a legítima defesa.

\section{DEFENDENDO A HONRA: O DUELO EM DEFESA DA DIGNIDADE PESSOAL.}

Em meados do século XVIII, em pleno ambiente intelectual iluminista, ninguém menos que o "pai" do liberalismo penal exprimiu em termos estritamente aristocráticos seu ponto de vista a respeito da honra e do tratamento a ser aplicado aqueles que a lesionassem por parte do direito penal.

Beccaria (2007, p.81) sustentou que a honra era um valor indispensável à própria existência do indivíduo. Inspirado neste pensamento, ele defendeu a tese de que seus titulares estariam autorizados a conservá-la mesmo que, para isto, precisassem usar de violência, numa espécie de retorno ao estado de natureza justificado pelo fato do soberano não ter conseguido tutelá-la a contento nos termos em que havia se comprometido quando da celebração do contrato social. Estabelecida esta premissa, tornava-se curto o caminho para a admissão do duelo como meio de reação individual contra as ofensas dirigidas à honra daquele que foi desafiado.

O pensador milanês afirmou que de nada adiantaria a previsão de leis que proibissem duelos porque, em seu entendimento, os seres humanos temem muito mais serem vítimas de insultos e infâmias que a ameaça de castigo penal. Este raciocínio, porém, seria válido somente para os aristocratas, haja vista que "o povo miúdo habitualmente não se bate em duelo como os grandes" tanto por não possuir armas como em razão da "necessidade de sufrágio dos outros ser menos comum na plebe do que naqueles que, sendo de categoria superior, se olham com maior inveja e desconfiança" (BECCARIA, 2007, p.82).

Porém, no que diz respeito aos duelos e a possibilidade de sua proibição legal, Beccaria (2007, p.82) posicionou-se favoravelmente à punição exclusiva do desafiante com a exclusão daquele que "sem culpa sua foi constrangido a defender o que as leis naturais não asseguram - a opinião - e teve que demonstrar aos seus concidadãos que teme somente as leis, mas não os homens".

Registre-se que em passagem alguma de sua obra célebre Beccaria menciona a possibilidade de reparação pecuniária do dano causado pela ofensa à honra alheia. Para ele, de acordo com a sua moral aristocrática, o duelo seria a única via a ser percorrida pelo indivíduo que pretende restaurar a dignidade violada. Quanto ao "povo miúdo", o milanês nele pouco ou quase nada se deteve. Pareceu-lhe que a honra seria, em definitivo, um valor apreciado exclusivamente pela camada aristocrática da sociedade. Embora ele reconhecesse que o duelo atenta contra a ordem pública, não viu sentido algum em punir aquele que preserva sua dignidade pessoal diante daqueles que a ofendem. Em seu sentir, somente quem atenta contra a honra alheia deveria ser merecedor de punição. 
Menos de um século após a publicação da obra de Beccaria que revolucionou o pensamento penal, em plena Inglaterra, o herói de Waterloo, violando as leis inglesas, bateu-se em duelo contra um adversário político.

Primeiro Ministro britânico, em 1829, Wellington defendeu na Câmara dos Lordes a Lei da Liberação Católica, que permitiria aos católicos tomarem assento no Parlamento, proibição que vigorava há mais de cento e cinquenta anos. $\mathrm{Na}$ época, um católico que pretendesse ser eleito para ocupar um assento no Parlamento britânico somente poderia fazê-lo se prestasse juramento de que "a invocação ou adoração da Virgem Maria ou de qualquer outro Santo, e o Sacrifício da Missa, como são agora usados na Igreja de Roma, são supersticiosos e idólatras". Os termos do referido juramento desestimulava os católicos a proferi-lo, eliminando, assim, seus direitos políticos (APPIAH, 2012, p.25).

Inconformado com a proposta de emancipação política dos católicos, um parlamentar inglês afirmou que o Primeiro Ministro estava agindo contra a causa protestante, tendo acrescentado a este ataque um outro onde dizia que Wellington teria se comportado de maneira oportunista ao oferecer apoio financeiro à criação do King's College de Londres, que seria uma instituição anglicana, para contrabalançar a instalação da laica Universidade de Londres. Em que pese a reação contra o projeto de lei, algumas semanas depois o monarca britânico sancionou a Lei da Liberação Católica em meio a boatos de que, pressionado pelo Primeiro Ministro, teria chorado ao assinar sua promulgação (APPIAH, 2012, p.26-27).

Sentindo-se ferido em sua dignidade pessoal, na medida em que havia sido acusado de trair sua fé e a Constituição, o vencedor de Waterloo exigiu a retratação de seu detrator, que se negou a fazê-lo. Diante da situação, certamente sentindo-se sem alternativas, Wellington o desafiou para um duelo. O problema, entretanto, é que o duelo era ilegal na Inglaterra segundo seu direito consuetudinário, além de ser condenado pelo direito canônico e pela doutrina moral cristã. Em consequência, caso o herói da Europa matasse seu adversário na disputa ele poderia ser julgado pela Câmara dos Lordes por ter cometido homicídio ou, na melhor das hipóteses, ter que renunciar ao cargo de Primeiro Ministro por ter desafiado alguém para duelo. Por fim, merece registro o fato de que o próprio Wellington era um adversário da prática do duelo. Em resumo, o duelo era contrário ao direito, estava em desacordo como direito canônico e com a moral cristã, era politicamente desastroso e, como se não bastasse, contrariava as inclinações pessoais do Primeiro Ministro. Mesmo assim, Wellington desafiou seu desafeto para duelar consigo por entender que, assim agindo, defendia sua honra, reafirmando, dessa maneira, o direito a ser respeitado pelos seus pares e, de maneira mais geral, por todo o reino. Ao mesmo tempo, seu comportamento assegurava o merecido respeito ao seu oponente que com ele compartilhava a condição de cavalheiro (APPIAH, 2012, p.28-30). 
Wellington nem matou nem morreu no duelo. Sabe-se ter sido ele quem efetuou o primeiro disparo, tendo errado o alvo. Em seguida, o desafiado apontou a sua pistola para o ar e disparou a arma, desistindo, assim, de tentar matá-lo. Assim agindo, este último demonstrou claramente sua intenção de não dar prosseguimento ao duelo. Este tipo de conduta por parte do desafiado poderia parecer insultuosa, mas, bem pesadas as circunstâncias, tinha sua razão de ser. Appiah (2012, p.42-43) explica convincentemente que a presença de Wellington - um cavalheiro -, no duelo, arriscando-se a morrer, demonstrava satisfatoriamente que ele era digno de respeito. Já no tocante ao desafiado, a situação era diferente, pois caso ele atirasse e matasse o Duque isto demonstraria tão somente que era um bom atirador e mais nada, ao contrário do herói da Europa que, honradamente, arriscava-se a aceitar um tiro que poderia ser fatal contra sua pessoa.

Este episódio, comum em suas linhas gerais a outros que ocorreram no século XIX, mostram claramente o descompasso existente entre a maior parte da legislação europeia que, na época, proibia terminantemente os duelos e o sentimento de cavalheiresco de honra pessoal ainda em vigor na camada aristocrática da sociedade. Embora setores majoritários da sociedade europeia condenassem veementemente a prática do duelo, a sobrevivência do costume e da moral aristocrática impunham resistência à sua abolição no plano do cotidiano. Fenômeno semelhante ocorreu no Brasil, país no qual os Tribunais do Júri costumavam absolver os maridos traídos que matavam suas esposas em nome da honra.

\section{DEFENDENDO A HONRA: A LEGÍTIMA DEFESA CONTRA O DESRESPEITO.}

Dentre as diversas causas de justificação contempladas na legislação penal brasileira, talvez nenhuma seja mais conhecida e discutida pela sociedade que a legítima defesa.

Em nome da autodefesa, a legítima defesa foi concebida inicialmente como justificante destinada à tutela da vida e da integridade física, contudo, ampliou posteriormente seu escopo de maneira a abranger territórios mais extensos. Atualmente, admite-se que a legítima defesa objetiva não somente a proteção da vida e da integridade física, mas também, por exemplo, da liberdade de locomoção, da liberdade sexual, do patrimônio, dentre outros bens jurídicos. De acordo com a doutrina penal, mesmo a honra pode ser conservada mediante a legítima defesa, desde que, naturalmente, observados o conjunto de requisitos objetivos e subjetivo da referida causa de justificação (PRADO, 2000, p.252; TOLEDO, 1991, p.199; PACELLI, CALLEGARI, 2015, p.231). Hoje, porém, a jurisprudência tem rechaçado explicitamente a possibilidade do reconhecimento da legítima defesa da honra na hipótese em que o marido mata a esposa infiel. Nas últimas décadas, Tribunais têm proclamado reiteradamente que "a infidelidade da mulher não desonra o homem que com ela vive, não podendo se falar em legítima defesa” nesses casos (TJRS, 1995). 
No ocaso do século passado, Tribunais, com respaldo doutrinário, ainda reconheciam a legítima defesa da honra em determinadas situações. Assim, por exemplo, o Tribunal de Justiça do Estado do Paraná (1993) admitiu a referida justificante para absolver o acusado que desferiu um tapa na vítima após ser verbalmente ofendido por ela. Não obstante, este entendimento ecoava ensinamentos doutrinários vetustos, muito embora, mesmo na última década do século anterior, a doutrina penal ainda afirmasse o seguinte a respeito da legítima defesa da honra: "Tem-se admitido a legítima defesa contra injúria verbal mesmo com desforço físico, desde que atendidos o requisito da moderação e os demais pressupostos do instituto" (MESTIERI, 1999:147).

$\mathrm{Na}$ realidade, posicionamentos mais prudentes podem ser encontrados mesmo na doutrina penal nacional mais antiga. Verificam-se entendimentos doutrinários que demonstram evidente inconformismo com a possibilidade do reconhecimento excessivamente amplo da legítima defesa contra ofensa à honra. Garcia (1963, p.311-312), por exemplo, somente admitia a legítima defesa da honra na hipótese da presença do requisito "objetividade", vale dizer, se a reação defensiva tivesse sucedido uma agressão física. Portanto, diz ele, há legítima defesa da honra quando um homem repele uma bofetada que atingiu seu rosto independentemente, inclusive, da existência de intuito ultrajante no golpe desferido pelo agressor. Neste caso, afirma o autor paulista, "a vítima da ofensa, simultaneamente material e moral, poderá repeli-la legitimamente, desde que proceda com moderação, em atividade proporcional ao ataque recebido".

O cerne do problema quase sempre residiu na avaliação da intensidade da reação em defesa da honra à luz da lesividade da agressão injusta, de maneira a verificar a existência ou não de uma espécie de proporcionalidade em sentido amplo entre a gravidade da ofensa e a forma assumida pela resposta do defendente. Esta operação mental, afirmava a doutrina, considerava a necessidade da existência de uma espécie de equilíbrio entre o ataque injusto e a defesa justa baseada na valoração do bem jurídico ameaçado, nas circunstâncias em que o defendente atuou e, por fim, nos meios concretos de que este podia dispor para repelir a agressão (BRUNO, 1978, p.380). De fato, apesar da letra fria do artigo 25, do Código Penal, não fazer menção ao requisito "proporcionalidade", o tipo permissivo o prevê implicitamente quando se refere aos requisitos "necessidade" dos meios utilizados e "moderação" em seu emprego pelo defendente. ${ }^{3}$

Seja como for, refletindo uma concepção moral arcaica a respeito da honra, Tribunais têm proferido decisões verdadeiramente teratológicas com fundamento no instituto da legítima defesa. Assim, por exemplo, o Tribunal de Justiça do Rio Grande do Sul (1998) reconheceu a necessidade e moderação e, consequentemente, a legítima defesa, no

3 Artigo 25, Código Penal: "Entende-se em legítima defesa quem, usando moderadamente dos meios necessários, repele injusta agressão, atual ou iminente, a direito seu ou de outrem". 
comportamento do agente que desferiu um tiro de espingarda em revide a uma ofensa verbal proferida por agressor quando este se encontrava a uma distância que impossibilitava o desforço físico do agredido. Na mesma linha, o Tribunal de Justiça de Santa Catarina (1998) admitiu a "legítima defesa do lar e da honra" para absolver um pai que, surpreendendo o ofendido na companhia de sua filha no quarto desta última, o agrediu, provocando-lhe ferimentos leves. Também o Tribunal de Justiça do Espírito Santo (1996) absolveu com fundamento na legítima defesa da honra o acusado que revidou agressão verbal da amásia e ofendeu sua integridade física porque esta última o chamara de "corno" e de "chifrudo".

Embora decisões judiciais semelhantes às mencionadas no parágrafo anterior tenham se tornado cada vez mais raras, expressando, assim, a evolução moral da sociedade e dos Tribunais a respeito do problema da legítima defesa da honra, nada obsta que elas venham a se repetir, na medida em que a injúria permaneça criminalizada.

\section{DEFENDENDO A PRÓPRIA HONRA: O MILITAR DIANTE DA INJÚRIA.}

Provavelmente, o melhor exemplo da evolução da mentalidade dos integrantes dos Tribunais superiores no tocante à legítima defesa da honra tenha ocorrido, em um curto espaço de tempo, no âmbito do Superior Tribunal Militar.

Em muitas sociedades a honra foi considerada, sobretudo, um atributo da aristocracia. Esta concepção remanesce em comunidades que, no presente, consideram válida a diferenciação entre pessoas que precisam defender sua honra de maneira mais enérgica e aquelas que não necessitam fazê-lo. Os primeiros são facilmente identificáveis porque combinam, por um lado, uma "total tranquilidade e autoconfiança, que surge do hábito do comando, com um notório nervosismo, uma sensibilidade intensa para ofensa e insultos, o sentimento de que o homem é, de algum modo, reduzido e humilhado se qualquer 'dívida de hora' acontecer de não ser paga” (GRAEBER, 2016, p.219). A própria doutrina penal do passado reconhecia a distinção entre "homens de honra" e "homens comuns". Noronha (1996, p.131-132), por exemplo, mesmo tendo afirmado a existência de um sentimento mínimo de dignidade e decoro em todo ser humano, sustentava o ponto de vista de que "nas baixas esferas, palavras altamente ofensivas, proferidas em tom amigável, não são tidas por injuriosas", razão pela qual, ainda segundo ele, em se tratando de defesa da honra, "a classe a que pertence a pessoa é, consequentemente, circunstância a se ter em vista". Em sua opinião, por exemplo, dentre as "classes" cuja honra sempre foi considerada passível de proteção por meios mais enérgicos encontra-se a militar.

Este ponto de vista doutrinário refletiu-se historicamente na jurisprudência do Superior Tribunal Militar. Na última década do século anterior, por exemplo, a Corte absolveu, com base na legítima defesa, um militar que causou lesão corporal em um colega de farda que lhe deu um empurrão. No acórdão absolutório, o Tribunal entendeu que 
"passaria por covarde, merecendo o desprezo, quem, nas dependências de seu local de trabalho, fosse agredido e não repelisse de pronto" o agressor (STM, 1996). Em pouco mais de dez anos, porém, a visão do Tribunal sobre a extensão da legítima defesa alterou-se radicalmente.

Manifestando-se em matéria de legítima defesa da honra, o Superior Tribunal Militar (2010) condenou Sargento da Aeronáutica que agrediu o namorado de sua ex-mulher pretextando ter atuado na tutela de sua dignidade pessoal. Também resultou em condenação a lesão corporal causada por um Cabo do Exército em um colega de farda que proferiu expressões galantes à sua esposa. No acórdão, o Superior Tribunal Militar (2011) argumentou expressamente que "a motivação ligada à crise de ciúmes não é capaz de isentar o réu de responsabilidade penal, por não ser aceita a tese da legítima defesa da honra”. Em julgamento ainda mais recente, o Tribunal condenou o agente pela prática do delito de lesão corporal por ter o militar provocado um dano à integridade física após entrar em luta corporal com indivíduo que o tinha chamado de ladrão (STM, 2014).

Pode-se perceber assim que, mesmo no ambiente militar, a concepção absoluta, aristocrática e cavalheiresca da honra tem cedido espaço a uma noção do referido valor mais adequada aos sentimentos da sociedade brasileira contemporânea.

\section{DEFENDENDO A PRÓPRIA HONRA: COMMODUS DISCESSUS E PROTEÇÃO DA DIGNIDADE PESSOAL.}

É unânime na doutrina penal nacional o entendimento de que não se pode exigir do titular do bem jurídico exposto a uma agressão injusta que empreenda a fuga mesmo podendo fazê-lo sem sofrer qualquer lesão. Em outras palavras, não se deve exigir que o agredido venha a fugir do agressor mesmo tendo condições de fazê-lo sem qualquer problema para si. Por conseguinte, admite-se que o agredido possa optar por repelir a agressão injusta ainda que venha a causar um dano a um bem jurídico do agressor. Nesta hipótese, todos concordam que ele teria atuando em legítima defesa.

Parte significativa da doutrina nacional fundamenta a possibilidade descrita no parágrafo anterior em argumento de natureza moralizante, mais especificamente na necessidade de tutela da honra do sujeito injustamente agredido. Assim, por exemplo, Noronha (1993, p.193) afirma que "a lei não pode impor ao indivíduo a pecha de covarde, vendo atingida a sua honra ao impedir o reconhecimento da legítima defesa por não fugir ao agredido". No mesmo sentido, REALE JÚNIOR (2002, P.159) argumenta que o direito penal "não pode exigir do agredido que arroste a pecha de covarde, vendo atingida a sua honra ao impedir o reconhecimento da legítima defesa por não fugir o agredido". Com as mesmas palavras de Noronha, o Tribunal de Justiça do Estado de São Paulo manifestou-se no sentido de que "é de todo indiferente à legítima defesa a possibilidade de fuga do 
agredido", na medida em que "a lei não pode exigir que se leia pela cartilha dos covardes e dos pusilânimes".

A doutrina penal militar nacional e estrangeira sempre foi igualmente permissiva. A doutrina penal militar italiana, por exemplo, costuma admitir que o agredido possa repelir a agressão injusta cometida contra sua pessoa mesmo podendo realizar comodamente a fuga, sobretudo "em se tratando de um militar, que tem o dever explícito de defender tenazmente os princípios de justiça, de não se mostrar covarde e de manter pura e intacta a honra militar" (CIARDI, 1970, p.210). Na mesma esteira, NUNZIATA (2004, p.95) assinala que, diferentemente de pessoa que possui uma qualidade específica ou subjetiva não incompatível com a fuga, a exemplo do sacerdote, "o sujeito que, ao contrário, veste uniforme, está revestido da condição de militar e tem uma noção de honra pessoal mais ampla que aquela dos civis comuns e pode expor sua própria pessoa a um prejuízo". Embora o autor reconheça que esta concepção possa parecer "anacrônica" e de "matriz cavalheiresca", ele esclarece que ela é acolhida pela legislação penal militar italiana. No Brasil, ROMEIRO (1994, p.134) posicionou-se em termos análogos, tendo dito que "se pode a fuga não afetar os brios de um civil, sendo até preferível no caso de agressão praticada por um inimputável, segundo alguns autores, o mesmo não ocorre com o militar", haja vista que "seu sentimento de honra, o pundonor militar, são incompatíveis com a fuga diante de qualquer agressor a direito seu ou de outrem".

De fato, o direito penal não impõe a fuga ao sujeito injustamente agredido por outrem, mas não em razão dos fundamentos moralizantes anteriormente expostos que apenas obstaculizam o progresso moral da sociedade. Na realidade, assiste razão a ROXIN (1997, p.633-634) quando afirma que "a legítima defesa não está destinada a provar a força e a coragem do agredido em dar uma lição a todos os agressores”, fundamentando-se, isto sim, nas noções de autotutela e de prevalência do direito sobre o injusto.

Em suma, pretendendo-se justificar juridicamente com fundamento na legítima defesa a reação daquele que, agredido injustamente, opta por repelir a agressão ao invés de empreender a fuga cômoda, deve-se fazê-lo não com apoio em argumentos moralizantes relacionados à preservação da honra, mas em bases propriamente jurídicas. O defendente que, podendo fazê-lo, não foge, atua em legítima defensa por ter assegurado que o direito prevalecesse sobre o injusto, consoante interpretação literal do artigo 25, do Código Penal brasileiro. Mesmo assim, em circunstâncias particulares, como na hipótese em que o agressor é inimputável ou quando o bem jurídico a ser tutelado é desproporcionalmente inferior aquele atingido pela conduta do defendente, há de ser exigida a fuga por parte deste último, desde que, evidentemente, possa realizá-la sem qualquer prejuízo à sua pessoa. 


\section{CONCLUSÃO: A TUTELA DA DIGNIDADE DA PESSOA HUMANA E O DIREITO PENAL MÍNIMO.}

No mundo contemporâneo, a honra merece proteção do direito, mas não do direito penal. A dignidade pessoal pode ser assegurada satisfatoriamente mediante o recurso à proteção que lhe é conferida pelo direito civil traduzida numa sanção de natureza pecuniária. Historicamente, inclusive, nem sempre a honra foi tutelada por meio da promessa da aplicação ao infrator da pena privativa de liberdade. Mesmo em tempos remotos, medidas mais brandas que a pena de morte, que o castigo corporal ou a privação da liberdade foram consideradas suficientes no sentido de conservar a respeitabilidade das pessoas atingidas em sua honra. Por conseguinte, inclusive, todo e qualquer revide violento contra injúria puramente verbal há de ser considerado excessivo. Pela mesma razão, mostra-se equivocado o entendimento doutrinário de que a fuga cômoda diante do autor de uma agressão injusta deve ser permitida para evitar que o agredido seja considerado atingido em sua honra em decorrência de um comportamento covarde, isto é, desmoralizador. Muito embora todo e qualquer ser humano mereça ter sua dignidade pessoal preservada contra agressões, uma concepção antiquada, aristocrática, cavalheiresca da honra tem o condão de exacerbar os conflitos intersubjetivos e de estimular a violência, precisando ser imediatamente abandonada pelo legislador penal, pela doutrina e pelos Tribunais.

O direito penal de garantias característico do Estado democrático de direito, amplamente fundamentado em princípios de natureza constitucional, a exemplo do princípio da intervenção mínima, precisa estar atento à necessidade de descriminalizar condutas que atentam contra bens jurídicos que possam ser tutelados a contento por meios extrapenais e mesmo extrajurídicos de proteção. Neste sentido, uma política criminal condizente com o espírito constitucional e com o direito penal liberal precisa esforçar-se para descriminalizar as condutas ofensivas a honra atualmente tipificadas na legislação penal codificada e extravagante, contribuindo, assim, para reforçar a consciência social no que diz respeito à necessidade de redução da violência em todos os seus níveis.

\section{REFERÊNCIAS}

APPIAH, K. A. O código de honra: como ocorrem as revoluções morais. Trad. Denise Bottmann. São Paulo: Companhia das Letras, 2012.

ARISTÓTELES. Ética a Nicómaco. Trad. José Luis Calvo Martínez. Madrid: Alianza, 2001. BECCARIA. Dos delitos e das penas. 2.ed. Trad. José de Faria Costa. Lisboa: Fundação Calouste Gulbekian, 2007. 
BRUNO, A. Crimes contra a pessoa. 4.ed. Rio de Janeiro: Editora Rio, 1976.

BRUNO, A. Direito penal: parte geral. 3. ed. Rio de Janeiro: Forense, 1967.

CIARDI, G. Trattato di diritto penale militare: parte generale. Roma: Bulzoni, 1970, v.1. GARCIA, B. Instituições de direito penal. 4. ed. São Paulo: Max Limonad, 1963, v.1, t.1. GRAEBER, D. Dívida: os primeiros 5.000 anos. Trad. Rogério Bettoni. São Paulo: Três Estrelas, 2016.

HESSEN, J. Filosofia dos valores. Trad. L. Cabral de Moncada. Coimbra: Arménio Amado, 1980.

MESTIERI, J. Manual de direito penal: parte geral. Rio de Janeiro: Forense, 1999, v.1. MOMMSEN, T. Derecho penal romano. Trad. P. Dorado. Bogotá: Temis, 1999.

NORONHA, E. M. Direito penal. 28 ed. São Paulo: Saraiva, 1996, v.2.

NUNZIATA, M. Corso di diritto penale militare. Napoli: Jovene, 2004.

PACELLI, E.; CALLEGARI, A. Manual de direito penal: parte geral. São Paulo: Atlas, 2015. PRADO, L. R. Curso de direito penal brasileiro: parte geral. 2. ed. São Paulo: Revista dos Tribunais, 2000.

REALE JÚNIOR, M. Instituições de direito penal: parte geral. Rio de Janeiro: Forense, 2002, v.1.

ROMEIRO, J. A. Curso de direito penal militar: parte geral. São Paulo: Saraiva, 1994.

ROXIN, C. Derecho penal: parte general. Trad. Diego-Manuel Luzón Peña, Miguel Díaz y García Conlledo e Javier de Vicente Remesal. Madrid: Civitas, 1997, t.1.

SÁNCHEZ VÁSQUEZ, A. Ética. Trad. João Dell'Anna. 22. ed. Rio de Janeiro: Civilização Brasileira, 2002.

STM. AP 1996.01.047728-4 MS, de 27 de julho de 1996. Relator: José Sampaio Maia.

STM. AP 0000028-06.2009.7.01.0301 RJ, de 28 de outubro de 2010. Relator: Marcos Augusto Leal de Azevedo.

STM. AP 0000039-80.2008.7.08.0008 PA, de 16 de maio de 2011. Relator: José Américo dos Santos.

STM. AP 0000150-77.2013.7.11.0211 DF, de 14 de outubro de 2014. Relator: William de Oliveira Barros.

THONISSEN, J. J. Le droit pénal de la republique athénienne. Bruxelles: BruylantChristophe \& Comp., 1875.

TJES. Tribunal de Justiça do Estado do Espírito Santo. ACR 56950000333, da 1a Câmara Criminal, Vitória, ES, de 11 de setembro de 1996. Relator: Osly da Silva Ferreira.

TJPR. Tribunal de Justiça do Estado do Paraná. AC 0058100-2, da $4^{\text {a }}$ Câmara Criminal, Curitiba, PR, de 29 de abril de 1993. Relator: Juiz Maranhão de Loyola. 
TJRS. Tribunal de Justiça do Estado do Rio Grande do Sul. AC 695125492, da 1a Câmara Criminal, Porto Alegre, RS, de 08 de novembro de 1995. Relator: Guilherme Oliveira de Souza Castro.

TJRS. Tribunal de Justiça do Estado do Rio Grande do Sul. AC 698382348, da 2a Câmara Criminal, Porto Alegre, RS, de 17 de dezembro de 1998. Relator: Walter Jobim Neto. TJSC. Tribunal de Justiça de Santa Catarina. RT 544/398. Relator: Marcílio Medeiros. TJSP. Tribunal de Justiça do Estado de São Paulo. RT 474/297. Relator: Villa da Costa. TOLEDO, F. de A. Princípios básicos de direito penal. 4. ed. São Paulo: Saraiva, 1991. 